\title{
Evaluating the Efficiency of a New Cutterhead Design to Counteract the Drawbacks of Excavation through Very Hard Rocks
}

\author{
Roohollah Narimani Dehnavi', Masoud Sadeghi², Nikolaus August Sifferlinger', and Rohola Hasanpour ${ }^{3}$
}

${ }^{1}$ Montanuniversitaet Leoben, Leoben, Austria

${ }^{2}$ Rayab Consulting Engineers Co., Tehran, Iran

${ }^{3}$ BabEng GmbH, Hanover, Germany

Received March 23, 2021; accepted April 22, 2021; published online June 2, 2021

\begin{abstract}
The application of appropriate excavation equipment in difficult grounds is of crucial importance and consequently improves the performance of hard rock Tunnel Boring Machines (TBMs). The cutterhead is one of the main components of TBMs which is directly involved in the excavation process, and its design can highly affect the cutting efficiency, the overall balance of the head, the performance of main bearing in long term, and the wear of the whole cutting face and muck buckets. This paper mainly focuses on the significant role of a proper design on the cutting efficiency with reference to a TBM tunneling project. Due to existence of very hard and abrasive rocks on the path of Kerman water conveyance tunnel, a new cutterhead was designed to be applied on a second hand TBM. The new cutterhead contains larger 19-inch disc cutters with a new disc cutter layout. Since the new cutterhead was launched following the excavation of the old one in a specific chainage of the tunnel, the performance of the two cutterheads in pyroclastic rocks could be compared with respect to the cutting efficiency, and lower specific energy values were observed for the new cutterhead which is the indicator of a better cutting efficiency in this geological condition.
\end{abstract}

Keywords: Cutterhead design, Cutting efficiency, Specific energy, Very hard rocks

\footnotetext{
R. Narimani Dehnavi $(\square)$

Montanuniversitaet Leoben,

Franz Josef Straße 18

Leoben, Austria

r.narimani@unileoben.ac.at
}

Evaluierung der Effizienz eines neuen Schneidkopfdesigns, um den Nachteilen des Schneidens in sehr hartem Gestein entgegenzuwirken

Zusammenfassung: Der Einsatz einer geeigneter Vortriebsausrüstung in schwierigen Böden ist von entscheidender Bedeutung und verbessert folglich die Leistung von Tunnelbohrmaschinen (TBM) in hartem Gestein. Der Schneidkopf ist eine der Hauptkomponenten von TBMs, die direkt in den Ausbruchsprozess involviert ist, und sein Design kann einen großen Einfluss auf die Schneideffizienz, die Gesamtbalance des Kopfes, die Leistung des Hauptlagers auf lange Sicht und den Verschleiß der gesamten Schneidwand und der Schaufeln haben. Dieser Beitrag konzentriert sich hauptsächlich auf die bedeutende Rolle eines geeigneten Designs auf die Schneideffizienz mit Bezug auf ein TBMTunnelbauprojekt. Aufgrund des sehr harten und abrasiven Gesteins auf der Strecke des Wasserleitungstunnels in Kerman wurde ein neuer Schneidkopf entwickelt, der auf einer gebrauchten TBM eingesetzt wird. Der neue Schneidkopf enthält größere 19-Zoll-Schneiddisken mit einer neuen Schneidkopfauslegung. Da der neue Schneidkopf nach dem Ausbruch des alten Schneidkopfes in einem bestimmten Abschnitt des Tunnels in Betrieb genommen wurde, konnte die Leistung der beiden Schneidköpfe in pyroklastischem Gestein in Bezug auf die Schneidleistung verglichen werden, und es wurden niedrigere spezifische Energiewerte für den neuen Schneidkopf beobachtet, was ein Indikator für eine bessere Schneidleistung in diesem geologischen Zustand ist.

Schlüsselwörter: Schneidkopfdesign, Schneidleistung, Spezifische Energie, Sehr hartes Gestein 
Fig. 1: The two cutter heads applied to Hallandsas tunneling project a The original cutterhead with $17^{\prime \prime}$ disc cutters and higher opening ratio $b$ The second modified cutterhead with $19^{\prime \prime}$ disc cutters and lower opening ratio
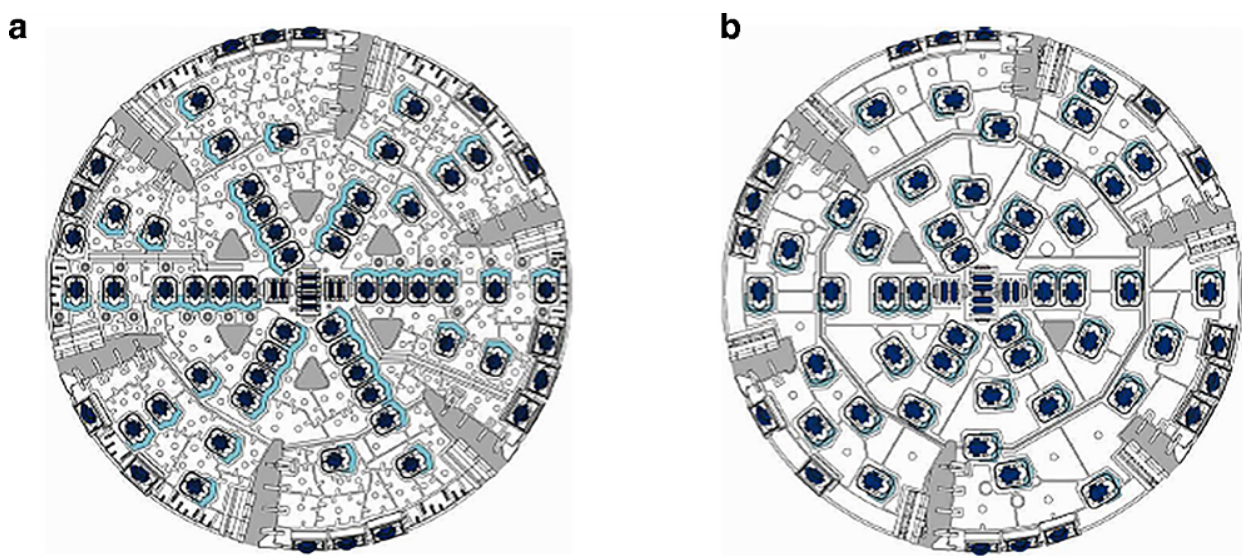

\section{Introduction}

Tunnel Boring Machines (TBM) have been widely used for tunneling through hard rock over the last few decades. Yet, an efficient and economic use of TBMs necessitates a comprehensive study on their main features and anticipated machine performance, since these machines are capital intensive and are unit operation systems, meaning that any stoppage of any component in the system will result in halting the entire operation. An efficient and highly productive operation can be partially fulfilled by ensuring the proper cutterhead design through an optimization process that largely depends upon its interaction with a rock. To achieve this aim, the effective interaction factors including rock mass properties and TBM operation parameters should be taken into consideration. An appropriate recognition of these factors is the prerequisite of the cutterhead design process.

Among various characteristics of TBM cutterheads, the dimension and layout of muck buckets, the layout of disc cutters and cutterhead shape have proven to be directly effective on the excavation performance [1-4]. In addition, different geological scenarios considerably affect the cutterhead behavior that consequently influences the overall performance of TBMs [3,5]. For example, in tunneling through weak rocks, it has been proved that the distance of mucks running in the gap between tunnel face and cutterhead should be reduced [6]. When excavating through very hard and blocky grounds, however, fewer openings and higher degrees of freedom in disc cutter arrangement are more preferable. Otherwise, in rocks with high abrasivity, secondary wear of mucks on cutters and cutterhead can be intensified. Excessive cutter wear leads to additional cost of disc cutters and requires additional time to replace the worn cutters [7]. Halandsas tunnel (Sweden, $L=8.70 \mathrm{~km}$ $\mathrm{D}=10.53 \mathrm{~m}$, Multi-mode TBM) is a good example for excessive cutter wear in a hard rock TBM project. According to the early geological investigations, a mixed face condition with very hard rocks as well as sticky soil were anticipated along certain stretches of tunnel, combined with high groundwater pressure and potential for high water inflow, which required the use of a pressurized face TBM. A sufficient number and size of openings at the center and face of the cutterhead were needed to minimize potential problems with clogging risks in the closed mode. This led to fewer degrees of freedom for the placement of disc cutters, especially in the center area, which is not favorable for hard and blocky rocks. In the second cutterhead design, experiences gained through adverse geological conditions including the blocky grounds were re-evaluated and a potential soil-like ground behavior was regarded as less important. Therefore, as can be observed in Fig. 1, the diameter of the disc cutters was increased to $19^{\prime \prime}$ and some openings were eliminated to allow more freedom for the arrangement of disc cutters. Consequently, the daily cutterhead maintenance time was significantly reduced [8].

Designing the disc cutter layout generally includes determining the disc cutter spacing and optimizing the distribution of the cutters on the cutterhead. The selection of a suitable disc cutter spacing is considered as one of the principle factors for controlling the cutting efficiency. It has been reported that a small deviation from the optimum spacing leads to significant reduction in cutting efficiency [9]. Regarding the selection of an optimum spacing between disc cutters, Rostami proved that the hardest rock formation is a dominating factor in choosing the optimum spacing to assure an acceptable performance of TBM in such formations [3].

Due to numerous complexities accompanied with fracture mechanism during rock cutting, experimental studies have been considered for obtaining the optimum spacing between cutters in order to achieve realistic results in predicting the field performance [10-13]. In addition, the influence of confining stress and joint spacing on the optimum spacing of cutters has recently been assessed experimentally $[14,15]$. Besides, several researchers have developed

\begin{tabular}{|ll|}
\hline TABLE 1 \\
\begin{tabular}{|ll} 
The main specifications of Herrenknecht TBM S323 \\
\hline Excavation Diameter (m) & 4.65 \\
\hline Number of disc cutters & 31 \\
\hline Disc cutter diameter (mm) & 432 (17 inches) \\
\hline Cutterhead torque (nominal) (kN.m) & 1029 \\
\hline Thrust force (Main thrust cylinder) (MN) & 16.91 \\
\hline Installed power (KW) & 1250 \\
\hline
\end{tabular}
\end{tabular}




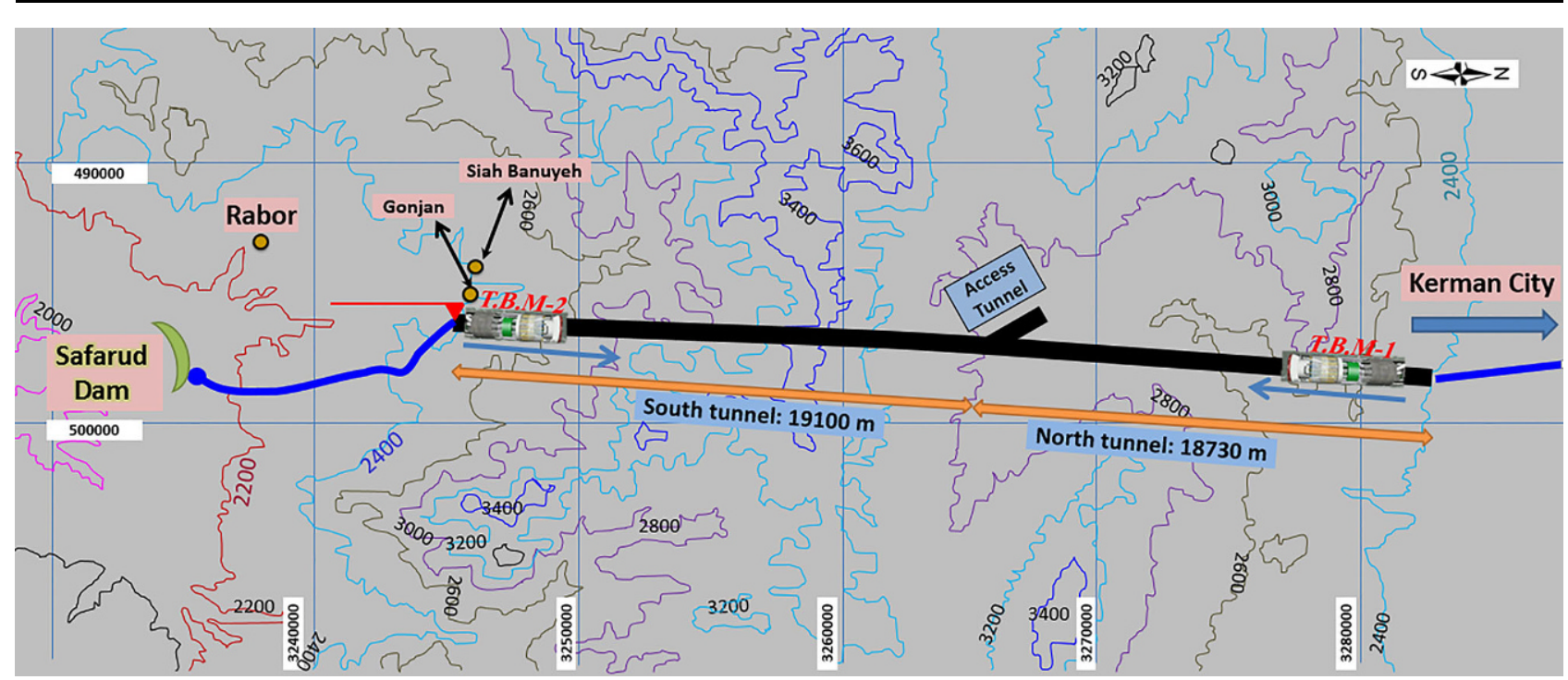

Fig. 2: The main components of Kerman water conveyance tunnel [23]

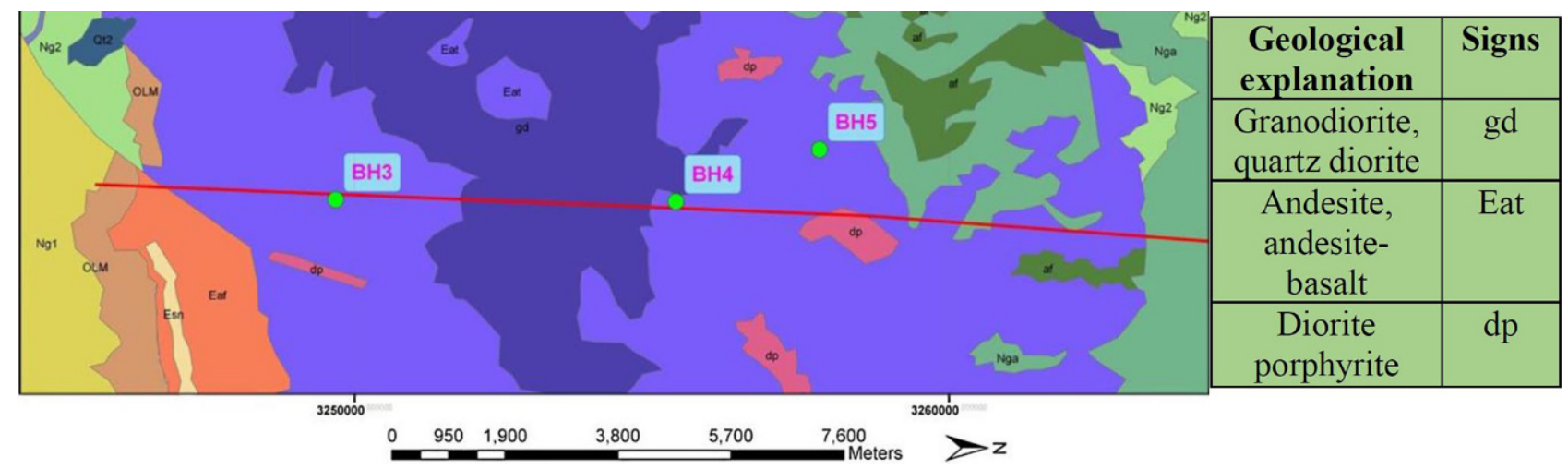

Fig. 3: Geological plan of southern part of Kerman water transmission tunnel

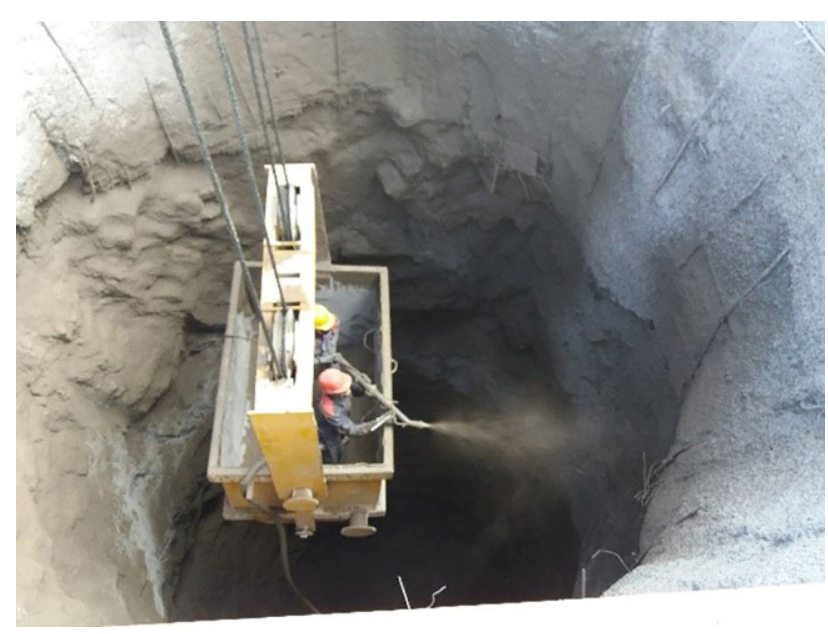

Fig. 4: The shaft excavated and supported for the assembly of the new cutterhead numerical simulations to present an insight into fracture process and effective geometric parameters [9, 16-21].

Specific engineering techniques are also required to improve the cutterhead layout. These techniques should satisfy the main requirements including minimizing the eccentric forces and moments of the cutter head, maximizing the number of successively cutting between two adjacent disc cutters, and reducing the overlapping area between disc cutters. Some other requirements, such as muck buckets and manhole positioning and the multi-segments assembly of cutterheads, impose limitations on this procedure [22]. For this purpose, Rostami [3] developed a modeling system for cutterhead layout optimization, which is capable of simulating various scenarios of ground conditions including mixed ground conditions and evaluating its effect on the magnitudes of moments and eccentric forces imposed on the cutterhead. This modeling system also enables the full rotation of the cutterhead.

Due to the complicated nature of rock mass, it might not always be straightforward to practically evaluate the extent of the efficiency of different designs in comparison to one another. In this research, the modifications applied on the design of a cutterhead in the tunneling project of Kerman, 
Fig. 5: The new cutterhead of TBM S323 to be applied on the northern lot of the Kerman tunnel
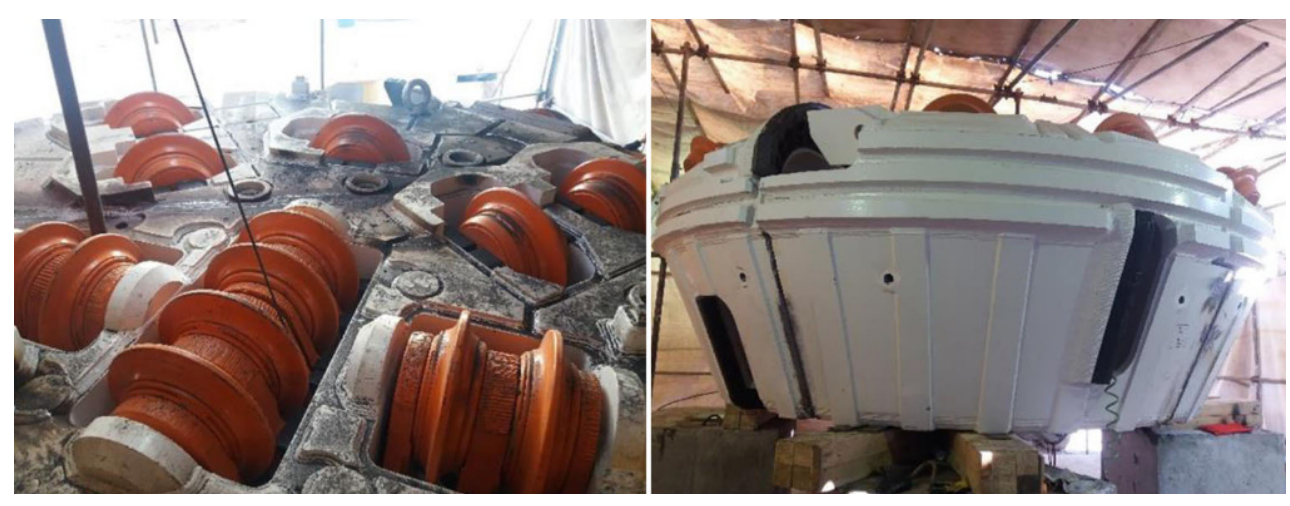

Fig. 6: a The old cutterhead structure. b The new cutterhead structure
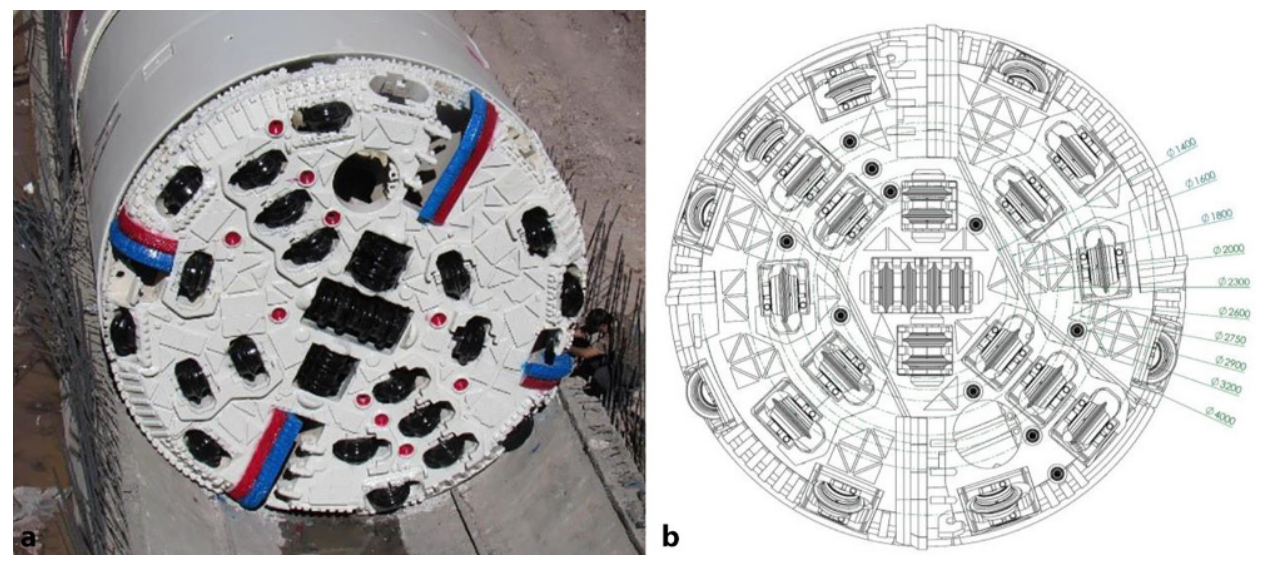

Iran, are described briefly and then the overall performance of the TBM in a specific geological condition is evaluated. Following an overall introduction to the project, an operational analysis on the performance of the new cutterhead is explained accordingly.

\section{Project Description}

The Safa dam water transmission system is a national project which is intended to transfer water from the Jazmourian watershed to the city of Kerman. Its main component is a $38 \mathrm{~km}$ tunnel, which is divided into two lots of $19 \mathrm{~km}$ length in the northern and southern parts of the route. Rabor town is situated close to the starting point of the south lot. The northern lot starting point is near Lalehzar. The focus of this study is on the northern lot, where a Herrenknecht double-shield TBM (S323) with the characteristics inserted in Table 1 is being applied to excavate a cross section of $4.65 \mathrm{~m}$ in diameter. Fig. 2 indicates different components of the whole project.

The whole tunneling region is situated in the central Iran zone and in the Orumieh-Bazman magmatic belt. The Eocene volcano-sedimentary rocks are pushed up over the Oligo-Miocene sedimentary formations (Ghom formation). The developed sedimentary deposits through the stress tectonic regions in the Oligo-Miocene epoch prove this fact. Indeed, these basins might have been Graben blocks formed by the thrust faults as a result of the dominant compressional stress regime in this epoch [24]. Ahourak Mountain consisting of volcanic-sedimentary sets plays the role of a tectonic uplift in the northern part of the tunnel. The Graben structure in the middle of the tunnel was made by Eocene volcanic rocks and intrusions. This brought about an area for sedimentation of neogene units of conglomerate and sandstone. In the southern tunnel, Oligo-
Fig. 7: The variation of thrust forces in the studied region of the tunnel (The blue graph represents the values pertaining to the old cutterhead and the orange graph is associated with the new cutterhead)

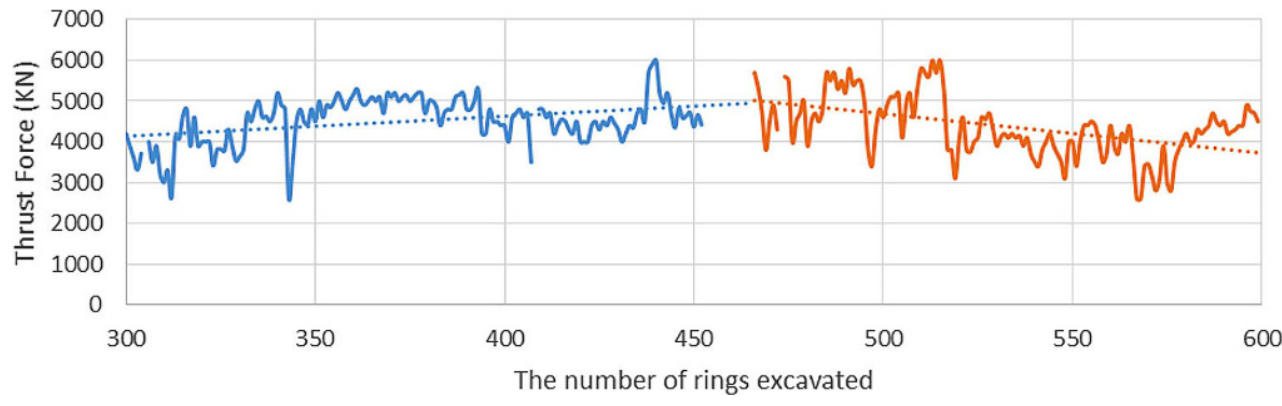




\begin{tabular}{|c|c|c|}
\hline Ring No. & $\begin{array}{l}\text { Average } \\
\text { value }(K N)\end{array}$ & $\begin{array}{l}\text { Standard } \\
\text { deviation (KN) }\end{array}$ \\
\hline $\begin{array}{l}300 \text { to } 465 \text { (before cutter- } \\
\text { head change) }\end{array}$ & 4520 & 575 \\
\hline $\begin{array}{l}465 \text { to } 600 \text { (after cutter- } \\
\text { head change) }\end{array}$ & 4360 & 750 \\
\hline
\end{tabular}

Miocene volcanic-sedimentary sets are situated on Eocene volcanic units with a slope to the west. A long proportion of the tunnel path consists of enormous masses of Granodiorite. Three of the boreholes drilled in the southern lot of the tunnel contained diorites with a uniaxial compressive strength (UCS) range of 100 to $260 \mathrm{MPa}$. In addition, the evaluation of surface samples collected from igneous rocks in the northern lot also indicated extremely strong rocks. Accordingly, it was necessary to implement appropriate designing principles for the TBM cutting tools. (Fig. 3).

\subsection{Selection of Suitable Cutting Tools}

By the non-stoppable modifications made on cutting tools, especially on disc cutters, during the last 50 years, the excavation through a wide range of rocks has been facilitated. The diameter of disc cutters is commonly in the range of 380 to $480 \mathrm{~mm}$ (15 to 19 inches). Among these, the most popular ones are 17-inch disc cutters [25]. In some cases, modifying the cutterhead has brought about the possibility of utilizing other cutting tools such as chisel tools[26].

In general, in cases of damages to the TBM cutterhead, a decrease in penetration rate and a rise in project duration are regarded as the main consequences of excavation through intensively strengthened rocks. In case of a wrong selection of excavation equipment, subsequent unwanted modifications under the ground might be necessary, which can be avoided by proper primary investigations [27]. A sig- nificant fall in the penetration rate might be the most important negative impact of excavation without the proper tools. In order to avoid such implications, a new cutterhead was designed for the second hand TBM of the northern lot of the Kerman tunnel. The new cutterhead applies 19inch disc cutters as the normal cutters instead of the 17inch disc cutters. The whole process of applying the new cutterhead including the ordering, design, and transportation was postponed due to various issues. In order to avoid any further escalation in the project duration and to ensure an acceptable progress, however, measures were taken to commence the project in the meanwhile. For this purpose, the TBM with all its backup components as well as the old cutterhead were overhauled and became ready to excavate the first $600 \mathrm{~m}$ of the northern lot of the tunnel. Meanwhile, a relatively short shaft was excavated by drilling and blasting in chainage of $600 \mathrm{~m}$ (Fig. 4). Following the excavation of the shaft and the $600 \mathrm{~m}$ length of the tunnel, the new cutterhead was assembled on the machine for excavation through the rest of the tunnel path (Fig. 5).

Fig. 6 shows the old and the new cutterhead structures. The new cutterhead is composed of 27 disc cutters, which has four fewer cutters compared to the old one with 31 disc cutters. The eight center cutters are 17 inches in size, while the others are of a greater size (19 inches). The spacing between the normal disc cutters is increased to $10 \mathrm{~cm}$ in the new cutterhead, which is a substantial change. Most of the other structural features, like the shape and the size of muck buckets, are kept the same.

\section{Evaluation of the New Cutterhead Performance}

Monitoring the operational parameters during the mechanized excavation is an important step towards understanding and analyzing the performance of TBMs and give valuable information regarding the performance of the machine [28]. Since both cutterheads had excavated a limited length of the tunnel with almost the same lithological states (An-

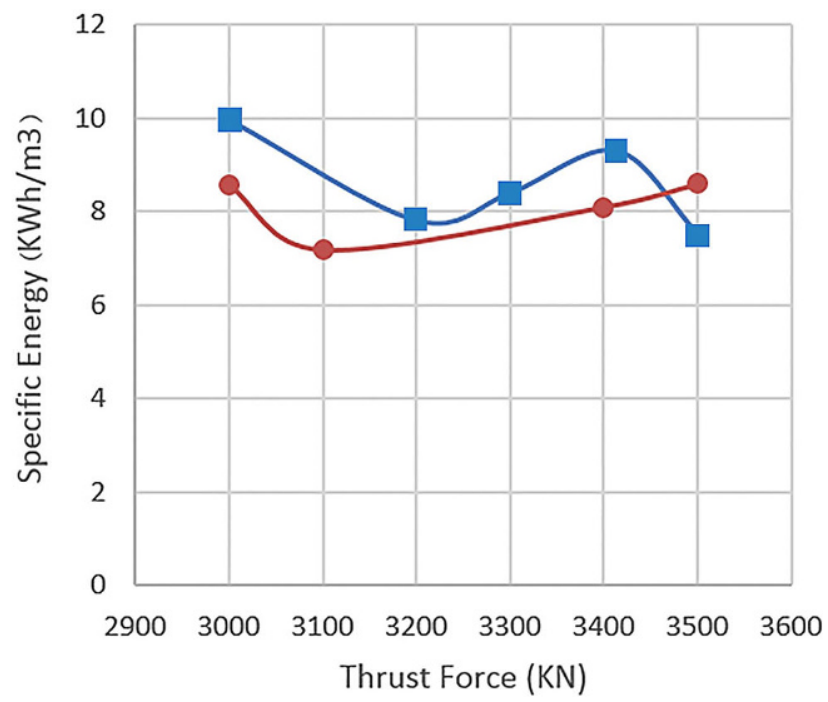


Fig. 9: Variation of specific energy values in the range of Thrust forces 4800 to $5200 \mathrm{KN}$
Fig. 10: Variation of specific energy values in range of Thrust forces 5200 to $6000 \mathrm{KN}$
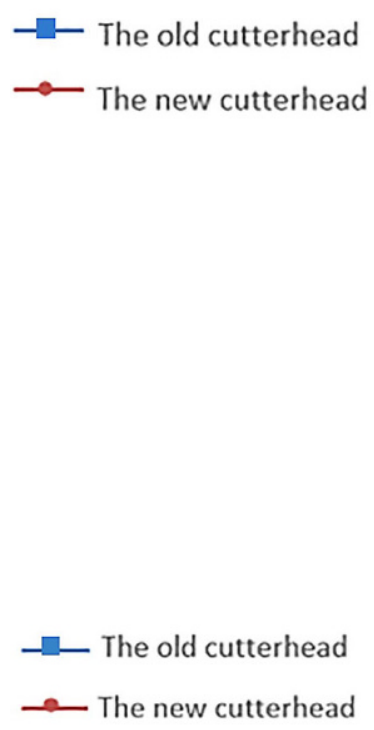
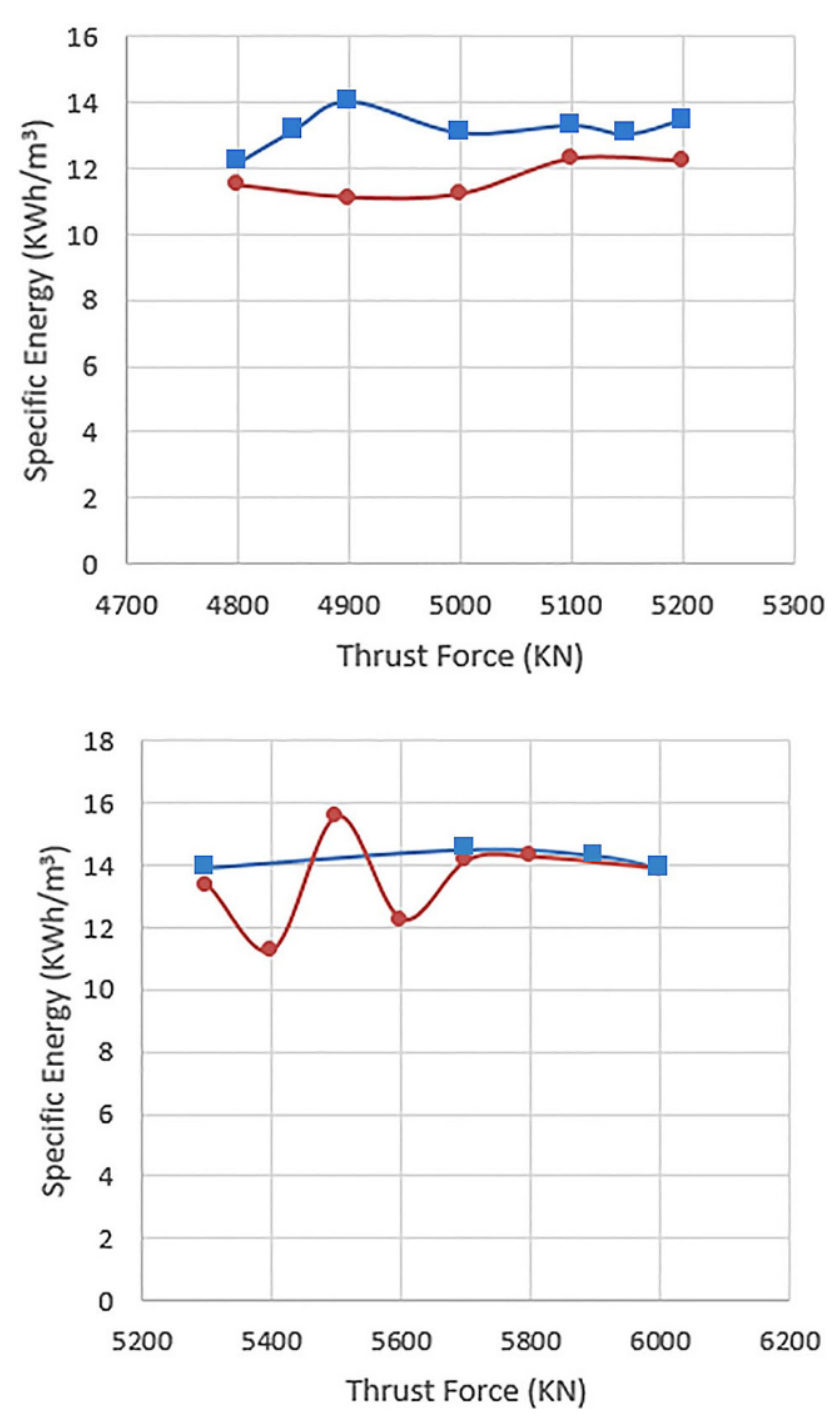

cated that a close monitoring of thrust force values of the machine make a great contribution to a better understanding of the geological condition. In general, a local reduction of the thrust value indicates an ease of excavation and in most cases it might represent a weaker material being excavated by the TBM. The variation of thrust force values is analyzed statistically in Fig. 7.

As can be seen in Fig. 7, a better consistency in the thrust force values was observed before the shaft chainage, whereas some minor fluctuations were seen in the following chainage excavated with the new cutterhead. This could be regarded as a result of limited changes in the strength of the rock mass or because of inevitable considerations of the operating crew in controlling the behavior of machine in the first stages of excavation. Nevertheless, the comparison of the average and standard deviation value of the machine thrust force shows close values of average, maximum, and minimum in both $200 \mathrm{~m}$ chainages (Table 2).

It should be noted that a factor affecting the thrust force values is the friction force, which is initiated as the cutterheads advance by considering their overall weight. In this analysis, their weight is assumed to be the same. 


\begin{tabular}{|c|c|c|c|c|c|c|}
\hline The thrust force ranges & Range 1 & Range 2 & Range 3 & Range 4 & Range 5 & Range 6 \\
\hline Proportion of the whole data (\%) & $8 \%$ & $7 \%$ & $21 \%$ & $31 \%$ & $24 \%$ & $9 \%$ \\
\hline $\begin{array}{l}\text { Average SE before new cutterhead assembling } \\
\text { (KWh/m3) }\end{array}$ & 8.2 & 8.9 & 10.3 & 11.9 & 13 & 14.1 \\
\hline $\begin{array}{l}\text { Average SE after new cutterhead assembling } \\
\text { (KWh/m3) }\end{array}$ & 8 & 9 & 9.9 & 11 & 11.6 & 14 \\
\hline Percentage of increase or reduction (\%) & - & - & $-4 \%$ & $-8 \%$ & $-11 \%$ & - \\
\hline
\end{tabular}

\subsection{Analysis of the Machine Performance by Specific Energy and Penetration Rate}

Specific energy is one of the most important factors for the determination of the rock cutting efficiency. The optimum specific energy can be applied to estimate the Net Penetration Rate. The amount of specific energy can be obtained in laboratory scale by linear cutting machines (LCM) or insitu by dint of operational parameters of the TBM. The following equation can be applied for the in-situ evaluation [29]:

$$
\mathrm{SE}_{\mathrm{f}}=2 \pi \cdot \mathrm{N} \cdot \mathrm{T} / \mathrm{PR}_{\mathrm{f}}
$$

$\begin{array}{ll}\mathrm{SE}_{\mathrm{f}}= & \text { Field Specific Energy }\left(\mathrm{kWh} / \mathrm{m}^{3}\right) \\ \mathrm{N}= & \begin{array}{l}\text { the cutterhead rotation speed }(\text { revolutions per } \\ \text { second) }\end{array} \\ \mathrm{T}= & \text { TBM torque }(\mathrm{KNm}) \\ \mathrm{PR}_{\mathrm{f}}= & \text { in-situ penetration rate }\left(\mathrm{m}^{3} / \mathrm{h}\right)\end{array}$

By employing the cutterhead rotation speed, the TBM torque as well as the in-situ penetration rate in the above equation, an approximation of the amount of specific energy in different sections of the tunnel can be achieved. After comparing the values before and after changing the cutterhead, the effect of the new cutterhead and its performance in terms of cutting efficiency can be assessed accordingly. The probable variations in the jointing condition, weathering of the rock mass and other geological factors, could definitely affect the applied excavation parameters and the specific energy calculations. In this regard, the values of specific energy were analyzed and compared in 6 different ranges of the thrust values so that the error extent can be minimized (Figs. 8, 9, and 10).

Tables 3 and 4 show the proportions of rise or fall in the amounts of Specific Energy (SE) and the penetration rate with respect to 6 ranges of thrust values. As a result, a re- duction of 4,8 , and $11 \%$ can be seen for Ranges 3,4 , and 5 , respectively. In the other three thrust ranges, however, no significant change is detected. It can be stated that $76 \%$ of the excavation data indicate a reduction of SE. Therefore, it can be concluded that the new cutterhead design could provide an acceptable efficiency in the cutting process of the studied tunnel region. Yet, the overall performance in harder rock formations cannot be compared individually with the previous state of the older cutterhead.

\section{Conclusions}

In summary, the proper design of a cutterhead affects directly the boring performance, service life, main bearing of the cutter head, vibration, and noise of the TBM [4].

The challenging factors that should be considered in the design and optimization of TBM cutterheads is choosing the right type of structural features on the cutterhead including the disc cutter type, spacing, and how the discs are distributed. In this research, the case study of the Kerman tunnel was studied in terms of the operational parameters to investigate the efficiency of a new cutterhead design. According to the primary geological studies, the tunnel was expected to encounter extremely hard rocks. Therefore, a new cutterhead was designed to counteract the drawbacks. In comparison to the old cutterhead which was equipped with 31 discs of a 17-inch size, the new one exhibited a lower consumption of energy during the excavation of pyroclastic rocks, which could indicate a more efficient design. Yet, other operational parameters especially the disc cutter consumption and the disc cutter performance during an excavation through hard and abrasive rocks demand further investigations. In addition, in-situ penetration tests are regarded as the most practical approaches which can give better insights into the performance of TBM cutterheads.

\begin{tabular}{|c|c|c|c|c|c|c|}
\hline The thrust force ranges & Range 1 & Range 2 & Range 3 & Range 4 & Range 5 & Range 6 \\
\hline Proportion of the whole data (\%) & $8 \%$ & $7 \%$ & $21 \%$ & $31 \%$ & $24 \%$ & $9 \%$ \\
\hline $\begin{array}{l}\text { Average penetration rate before new cutterhead } \\
\text { assembling }(\mathrm{mm} / \mathrm{rev})\end{array}$ & 6.7 & 8.85 & 6.7 & 6.45 & 6 & 5.8 \\
\hline $\begin{array}{l}\text { Average penetration rate after new cutterhead } \\
\text { assembling }(\mathrm{mm} / \mathrm{rev})\end{array}$ & 8.42 & 7.6 & 7.36 & 6.77 & 6 & 5.57 \\
\hline Percentage of increase or reduction (\%) & $+25 \%$ & $-14 \%$ & $+10 \%$ & - & - & - \\
\hline
\end{tabular}


Funding. Open access funding provided by Montanuniversität Leoben.

Open Access This article is licensed under a Creative Commons Attribution 4.0 International License, which permits use, sharing, adaptation, distribution and reproduction in any medium or format, as long as you give appropriate credit to the original author(s) and the source, provide a link to the Creative Commons licence, and indicate if changes were made. The images or other third party material in this article are included in the article's Creative Commons licence, unless indicated otherwise in a credit line to the material. If material is not included in the article's Creative Commons licence and your intended use is not permitted by statutory regulation or exceeds the permitted use, you will need to obtain permission directly from the copyright holder. To view a copy of this licence, visit http://creativecommons.org/licenses/by/4.0/.

\section{References}

1. Gehring, K.: The influence of TBM design and machine features on performance and tool wear in rock, Geomechanics and Tunnelling, 2 (2009), pp 140-155

2. Qi, G.; Zhengying, W.; Fei, H.; Hao, M.: Comparison of the mechanical performance between two-stage and flat-face cutter head for the rock tunnel boring machine (TBM), Journal of Mechanical Science and Technology, 29 (2015), pp 2047-2058

3. Rostami, J.: Hard Rock TBM Cutterhead Modeling for Design and Performance Prediction, Geomechanics and Tunnelling, 1 (2008), pp 18-28

4. Sun, W.; Huo, J.; Chen, J.; Li, Z.; Zhang, X.; Guo, L.; Zhao, H.; Zhao, Y.: Disc cutters' layout design of the full-face rock tunnel boring machine (TBM) using a cooperative coevolutionary algorithm, Journal of Mechanical Science and Technology, 25 (2011), p 415

5. Liu, J.; Ren, J.; Guo, W.: Thrust and torque characteristics based on a new cutter-head load model, Chinese Journal of Mechanical Engineering, 28 (2015), pp 801-809

6. Zhao, J.; Gong, Q. M.; Eisensten, Z.: Tunnelling through a frequently changing and mixed ground: $A$ case history in Singapore, Tunnelling and Underground Space Technology, 22 (2007), pp 388-400

7. Tanimoto, C.; Yamanaka, S.; Tsusaka, K.; Nakane, T.; Hirano, M.; Kanzaki, H.; Abe, S.; Iwata, S.: A Study on Cutter Wear and Mechanical Properties of Rocks in Tunneling with a TBM, Journal of the Society of Materials Science, Japan, 55 (2006), pp 29-36

8. Burger, W.; Dudouit, F.; Society for Mining and Exploration (U.S.) M.: The Hallandsas Dual Mode TBM, in 19th, Rapid excavation and tunneling conference, Littleton, Colo., Las Vegas, NV: Society for Mining, Metallurgy and Exploration, 2009, pp 416-437

9. Cho, J.-W.; Jeon, S.; Yu, S.-H.; Chang, S.-H.: Optimum spacing of TBM disc cutters: A numerical simulation using the three-dimensional dynamic fracturing method, Tunnelling and Underground Space Technology, 25 (2010), pp 230-244

10. Cho, J.-W.; Jeon, S.; Jeong, H.-Y.; Chang, S.-H.: Evaluation of cutting efficiency during TBM disc cutter excavation within a Korean granitic rock using linear-cutting-machine testing and photogrammetric measurement, Tunnelling and Underground Space Technology, 35 (2013), pp 37-54

11. Gertsch, R.; Gertsch, L.; Rostami, J.: Disc cutting tests in Colorado Red Granite: Implications for TBM performance prediction, International Journal of Rock Mechanics and Mining Sciences, 44 (2007), pp 238-246
12. Snowdon, R. A.; Ryley, M. D.; Temporal, J.: A study of disc cutting in selected British rocks, International Journal of Rock Mechanics and Mining Sciences \& Geomechanics Abstracts, 19 (1982), pp 107-121

13. Yang, W.; Xue, Y.; Zhang, X.: Experimental Study on Rock Fragmentation by the 19-inch TBM Cutter and Statistical Analysis of Debris in 8th Asian Rock Mechanics Symposium, (2014), Sapporo, 2014, pp. 1028-1037

14. Liu, J.; Cao, P.; Han, D.: The influence of confining stress on optimum spacing of TBM cutters for cutting granite, International Journal of Rock Mechanics and Mining Sciences, 88 (2016), pp 165-174

15. Yin, L.; Miao, C.; He, G.; Dai, F.; Gong, Q.: Study on the influence of joint spacing on rock fragmentation under TBM cutter by linear cutting test, Tunnelling and Underground Space Technology, 57 (2016), pp 137-144

16. Baek, S. H; Moon, H. K.: A numerical study on the rock fragmentation by TBM cutter penetrationNo Title, Tunnel and Underground Space, 13 (2003), pp 444-454

17. Gong, Q. M.; Zhao, J.; Hefny, A. M.: Numerical simulation of rock fragmentation process induced by two TBM cutters and cutter spacing optimization, Tunnelling and Underground Space Technology, 21 (2006), p 264

18. Liu, H. Y.; Kou, S. Q.; Lindqvist, P.-A.; Tang, C. A.: Numerical simulation of the rock fragmentation process induced by indenters, International Journal of Rock Mechanics and Mining Sciences, 39 (2002), pp 491-505

19. Zare Naghadehi, M.; Mikaeil, R.: Optimization of Tunnel Boring Machine (TBM) Disc Cutter Spacing in Jointed Hard Rock Using a Distinct Element Numerical Simulation, Periodica Polytechnica Civil Engineering, 61 (2017), pp 56-65

20. Moon, T.; Oh, J.: A Study of Optimal Rock-Cutting Conditions for Hard Rock TBM Using the Discrete Element Method, Rock Mechanics and Rock Engineering, 45 (2012), pp 837-849

21. Park, G.-I.; Jang, S.-H.; Choe, S.; Jeon, S.: Prediction of the optimum cutting condition of TBM disc cutter in Korean granite by the linear cutting test, (2006), 2006

22. Huo, J.; Sun, W.; Chen, J.; Zhang, X.: Disc cutters plane layout design of the full-face rock tunnel boring machine (TBM) based on different layout patterns, Computers \& Industrial Engineering, 61 (2011), pp 1209-1225

23. Narimani Dehnavi, Roohollah; Shamsaddini, Alireza; Koohsari, Ali; Rezaei, Ali Akbar; Khademi Hamidi, J.: Challenges of excavation through mixed-face grounds by hard rock TBMs: the case study of Kerman water conveyance tunnel, in International Conference on Tunnel Boring Machines in Difficult Grounds (TBM DiGs 2017), 2017

24. Shahabpour, J.: Island-arc affinity of the Central Iranian Volcanic Belt, Journal of Asian Earth Sciences, 30 (2007), pp 652-665

25. Roby, J.; Sndall, T.; Kocab, J.; Lindbergh, L.: Current state of disc cutter design and development directions, 61 (2009), pp 26-34

26. Bilgin, N.; Copur, H.; Balci, C.: Effect of replacing disc cutters with chisel tools on performance of a TBM in difficult ground conditions, Tunnelling and Underground Space Technology, 27 (2012), pp. 41-51.

27. Wittke, W.: Stability Analysis and Design for Mechanized Tunneling, (2007). Aachen: VGE-Verlag Glückauf GmbH, 2007

28. Sadeghi, Masoud; Narimani Dehnavi, R.: Using In situ penetration tests to improve the performance of TBM in long tunnels-Case study of Golab water transfer Tunnel, in 4th Dam and Tunnel Conference \& Expo, 2016, Tehran, 2016

29. Bilgin, Nuh; Copur, Hanifi; Balci, C.: Mechanical Excavation in Mining and Civil Industries, 1st ed., CRC Press, 2014

Publisher's Note. Springer Nature remains neutral with regard to jurisdictional claims in published maps and institutional affiliations. 